wish to qualify for practice in this branch of ophthalmology. A sub-committee has been appointed to consider the whole subject, and have already presented three reports which the Council are engaged in considering.

The Council have also had their attention drawn to the fact that the Hospital Savings Association has been encouraging their members to seek the advice of sight testing opticians ; and representatives of the Council together with those of the Ophthalmic Committee of the British Medical Association waited on the Hospital Savings Association Council at their offices and placed their case before them. The interview did not lead to any practical results, and both the Council and the British Medical Association are debating what further steps should be taken in the matter.

The expenses of the Council have, as usual, been defrayed by contributions from its members.

\title{
INTERNATIONAL ORGANIZATION OF THE CAMPAIGN AGAINST TRACHOMA AND INTERNATIONAL ASSOCIATION FOR PREVENTION OF BLINDNESS
}

On the occasion of the Annual Congress the Council of the Ophthalmological Society invited the International Organization of the Campaign against Trachoma and the International Association for the Prevention of Blindness to hold their annual meetings in London. The invitation was gratefully accepted by the sister societies, offspring of the International Council of Ophthalmology.

The International Organization of the Campaign against Trachoma held its first meeting on April 3 when Professor de Grosz (Hungary) announced his resignation of the office of President. He has filled the post most admirably since the foundation of the Organization in 1929. He has been succeeded as President by Mr. A. F. MacCallan (Great Britain), while Dr. F. Wibaut (Holland) remains as Secretary-General.

At the scientific meeting on April 3 the subject for discussion was "The social and legal measures to be taken against trachoma." After an introductory paper read by Mr. MacCallan*, reports of very great interest were read by Dr. Josephus Jitta (League of Nations), Dr. Tewfik (Egypt), Professor Miyashita (Japan), and Dr. Zachert (Poland).

\footnotetext{
* Published in May No.
} 
The International Association for the Prevention of Blindness met on April 5. Everyone regretted the unavoidable absence of Professor de Lapersonne; his presidential report was read by Professor Terrien. The scientific meeting was held the same day under the presidency of Dr. Park Lewis (U.S.A.). Professor van Duyse (Belgium) gave a résumé of an important paper on "Classification of the causes of Blindness" which was followed by short papers by Mr. Paton (Great Britain), Mr. MacCallan (Great Britain), Professor Marquez (Spain) and Mr. Bickerton (Great Britain). Professor Francheschetti (Switzerland) then read at full length a paper on "Hereditary Diseases of the Eyes."

It is proposed to hold a joint meeting of the two societies in Paris at the time of the annual congress of the Société française d'Ophtalmologie in May 1936. The subject for discussion will be "The treatment of trachoma : (a) when carried out by an ophthalmologist ; $(b)$ when carried out by a general practitioner."

Among the festivities arranged in honour of the foreign visitors there was a splendid entertainment given at Clothworkers' Hall by the Master and Wardens on April 3. They were the guests of the Council of the Ophthalmological Society at the Annual Dinner on April 4, and of Sir John Parsons and Mr. and Mrs. Leslie Paton at dinner on April 5, previous to attending a reception at Lancaster House given by His Majesty's Government.

\section{INTERNATIONAL ASSOCIATION FOR THE PREVENTION OF BLINDNESS}

The annual General Assembly of the International Association for the Prevention of Blindness was held on Friday, April 5, by the courtesy of the Royal Society of Medicine in the House of the Society.

The Executive Committee met in the morning. Dr. Park Lewis, of Buffalo, U.S.A., presided in the regrettable absence of Professor de Lapersonne, of Paris. The Report for the year was presented in French by Professor Terrien, and in English by Mr. Bishop Harman. The accounts showed an increase of contributions from French sources. An appropriation of 3,000 francs was voted for propaganda purposes in the formation of sight-saving classes in France. Professor van Duyse of Ghent was elected secretary-general, and Mr. MacCallan to represent Great Britain in place of $\mathrm{Mr}$. Cridland, whose early death was deplored. A joint meeting was arranged between the Association and the Organization against Trachoma to be held in Paris in 1936. The subject 